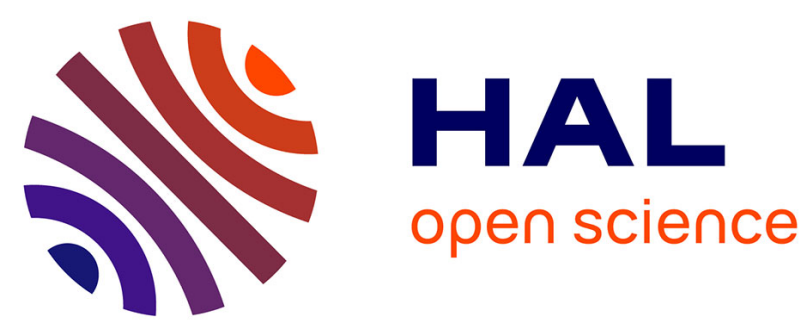

\title{
New syntheses of tetrazolylmethylphenylalanine and O-malonyltyrosine as pTyr mimetics for the design of STAT3 dimerization inhibitors.
}

\author{
Jennifer Dourlat, Bruno Valentin, Wang-Qing Liu, Christiane Garbay
}

\section{To cite this version:}

Jennifer Dourlat, Bruno Valentin, Wang-Qing Liu, Christiane Garbay. New syntheses of tetrazolylmethylphenylalanine and O-malonyltyrosine as pTyr mimetics for the design of STAT3 dimerization inhibitors.. Bioorganic and Medicinal Chemistry Letters, 2007, 17 (14), pp.3943-6. 10.1016/j.bmcl.2007.04.107 . inserm-00168682

\section{HAL Id: inserm-00168682 https://www.hal.inserm.fr/inserm-00168682}

Submitted on 30 Aug 2007

HAL is a multi-disciplinary open access archive for the deposit and dissemination of scientific research documents, whether they are published or not. The documents may come from teaching and research institutions in France or abroad, or from public or private research centers.
L'archive ouverte pluridisciplinaire HAL, est destinée au dépôt et à la diffusion de documents scientifiques de niveau recherche, publiés ou non, émanant des établissements d'enseignement et de recherche français ou étrangers, des laboratoires publics ou privés. 
New syntheses of tetrazolylmethylphenylalanine and O-malonyltyrosine as pTyr mimetics for the design of STAT3 dimerization inhibitors

Jennifer Dourlat, Bruno Valentin, Wang-Qing Liu and Christiane Garbay.

The novel syntheses of two pTyr mimetics, L-tetrazolylmethylphenylalanine (L-Tmp) and L-O-malonyltyrosine (L-OMT) are reported. Incorporation into a high affinity ligand of the STAT3 SH2 domain identified L-OMT as the first nonphosphorus pTyr mimetic reported so far against the STAT3 SH2 domain.

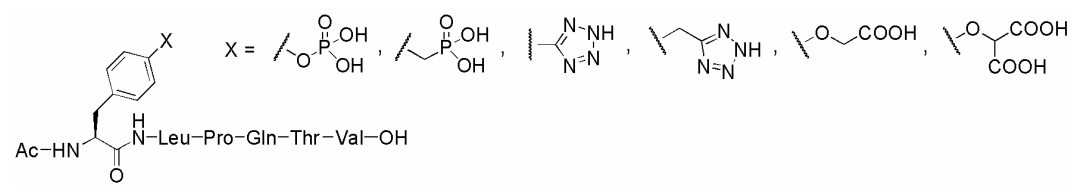

